\title{
Understanding the diffusion and adoption of digital finance innovation in emerging economies: M-Pesa money mobile transfer service in Kenya
}

\author{
Ann Njoki Kingiri (corresponding author) \\ African Centre for Technology Studies, \\ Nairobi, Kenya
}

Email: ankingiri@gmail.com

\section{Xiaolan $\mathrm{Fu}$}

Oxford Department of International Development

Technology and Management Centre for Development

University of Oxford, UK

Email: xiaolan.fu@qeh.ox.ac.uk

\begin{abstract}
The growth of digital financial innovations in emerging economies varies across countries with Kenya's mobile money transactions leading in Africa. Empirical evidence is lacking to describe from a system perspective the major factors attributing to this. Among the major money mobile transfer innovations, M-Pesa has recorded a tremendous impact since its launch in 2007.

Consequently, this paper uses M-Pesa as a case study to understand the determinants of success of digital financial innovations in an emerging economy. The analysis is applied at the level of technological innovation system (TIS), a framework that has provided useful insights into the functions that need to be stimulated for successful deployment of innovative technologies. The analysis exposes key systemic functions that characterize M-Pesa rapid diffusion in Kenya. From a theoretical perspective, the study finds that TIS framework can be applied to explain the diffusion of a foreign technology in a developing economy context. However, the local adaptation process attracts critical coordination aspects and significant learning and localized capabilities that may be attributed to rapid expansion of M-Pesa. These dynamic aspects are not explicitly articulated in the TIS literature. The study concludes with some policy oriented recommendations towards stimulation of key functions that may support diffusion of inclusive digital finance innovations in emerging contexts.
\end{abstract}

Key words: Digital finance innovation, mobile money, technological innovation system (TIS), M-Pesa, Kenya, 


\section{Introduction}

Discussions about technological revolution and prospects for technological innovation driven industrial growth have been unprecedented ( $\mathrm{Fu} \mathrm{2014).} \mathrm{This} \mathrm{implies} \mathrm{that} \mathrm{in} \mathrm{the} \mathrm{era} \mathrm{of}$ globalization, transfer, adoption and adaptation of technologies for economic and industrial growth is paramount (Ibid). There are indications that low and middle income countries are largely recipients of knowledge through a process of adoption and adaptation of technologies from abroad rather than creation of own local technologies (Lema et al. 2018). This notwithstanding, it is important to explore the factors that influence diffusion of new technologies because this is critical to understanding technological change and related social and economic impact (Bergek et al. 2008). Despite the importance of financial related technologies in stimulating innovation, there are very few empirical studies especially in developing countries that focus on adoption and diffusion aspects (Bara 2016; Kabanda 2014).

The growth of financial digital innovations especially in developing countries including Saharan African (SSA) has been unprecedented (GSMA 2016; Van der Boor, Olveira, and Veloso 2014; Heeks 2011). Kenya has a thriving mobile commerce transacted using mobile money and is leading in Africa with about $70 \%$ of the population using this service (GSMA 2015). There are several mobile money transfer services in Kenya but M-Pesa is leading in terms of subscribers with $80 \%$ market share (Sunday 2018; CA 2018).

There are a number of studies that have been undertaken to explore why M-Pesa has been successful. These have focused mainly on user side and technology supply side including entrepreneurship and business ecosystem environment, primarily at the macro level. At the time of writing this paper, there was no research that focuses on the systemic diffusion and adoption of digital finance innovations. This would be useful especially in SSA where growth in services attributed to information and communication technology (ICT) has been revolutionary (GSMA 2016). Consequently, the study seeks to understand the determinants of success (or failure) of digital financial innovations in an emerging economy through the lens of M-Pesa mobile money transfer service.

The study adopts a qualitative case study approach supported by an in-depth historical events' analysis of secondary materials, observation of M-Pesa transactions and interviews with selected actors in the digital finance sector. M-Pesa has recorded varying adoption rates in different countries, but it has shown significant growth in Kenya compared to other countries, hence the study country. This analysis is applied at the level of technological innovation system (TIS) framework that has provided useful insights into the functions that need to be stimulated for successful deployment of innovative technologies. The analysis finds that M-Pesa diffusion trajectory is characterized by a number of major system functions that interact significantly thereby leading to rapid piloting, up-scaling and expansion. The study further shows that the TIS framework can be applied to explain the diffusion of a technological innovation developed abroad, in a developing economy's context. However, the process of local adaptation that generates requisite knowledge and local capabilities is not explicitly articulated in the TIS literature.

The study has both policy and practice implications. It can help policy makers understand factors that affect diffusion and adoption of digital innovations with a view to streamlining related implementation regulations and strategies. For private sector actors like banks and entrepreneurs, in can help in various ways. For instance, it can inform in designing of appropriate business models for different markets. For researchers, the study identifies 
potential knowledge gaps and expands research perspectives to diffusion and adoption of emerging technologies in emerging economies. The paper is structured as follows. First is the introduction, followed by a brief overview of the framework that has informed the study. Third is the critical review of functions associated with M-Pesa diffusion and adoption in Kenya. Lastly is policy and practice oriented lessons drawn to contribute to the discussion about emerging innovations and diffusion in emerging economies.

\section{Methodology and analytical framework}

\subsection{Conceptual framework: adoption and diffusion of innovation}

\subsubsection{Innovation diffusion theories}

Rogers (2003) uses four elements to describe diffusion of innovations. These include innovation as new idea, practice or object, time factor that comprises of decision process, relative time of adoption and rate of adoption, communication channels and social system as set of interrelated units engaged in joint problem solving to accomplish a common goal. Rogers (2003) and Bara (2016) further explain that technology diffusion is a function of different factors including relative advantage or usefulness and ease of use. Other scholars draw insights from Rogers to differentiate diffusion concept from adoption. Amal et al. (2014) for instance describe diffusion as a macro process involving spread of a new product from source to target consumer. They describe adoption as a micro process comprising of decision path by an individual on whether to accept or adopt a product. The World Bank (2008) framework of diffusion of technologies in developing countries explains that technological absorptive capacity of a country depends largely on government and business climate, technology literacy and finance of innovative firms. The development scholars on the other hand emphasize the importance of learning and local capabilities in the transfer of foreign technologies into emerging economies mainly Africa (Lema, et al. 2018). In the case of financial innovations, developing countries have become lead innovators due to improved access to ICT enabled technologies among other factors (Van der Boor, Olveira, and Veloso 2014; Heeks 2011). Despite this positive trend, rapid diffusion in developing countries is constrained by internal factors like human capital, resources networking capabilities and external factors like country's macroeconomic factors and internal regulation (Bara, 2016).

\subsubsection{The TIS approach in analyzing innovation and diffusion}

The TIS approach is technology focused and because of its simplicity in scope, it makes it easy to explore the dynamics associated with characteristics, performance and evolutionary transformation of emerging systems. The proponents of this framework adopt a functional based approach to the analysis of activities and processes in a system. For instance, Bergek et al. (2008) and Hekkert et al. (2007, 2011) outline key system functions or processes that can be used to map the functional pattern of a TIS (Table 1). Mapping the respective functions and embedded interactions over different phases in a given time help to expose the nature of a TIS as well as the determinants of technological change. The operationalization of all or some of the seven functions or processes help to expose the dynamics that may influence the development, diffusion and deployment of new technologies in different contexts. It is important to note that different functions tend to reinforce one another positively or negatively (Hekkert et al. 2007).

Table 1: Overview of System Functions for analyzing a given TIS

\begin{tabular}{|l|l|}
\hline Function/ process & Description \\
\hline $\begin{array}{l}\text { F1: Entrepreneurial } \\
\text { activities }\end{array}$ & $\begin{array}{l}\text { Stakeholders participate in different activities that are experimental in nature. } \\
\text { These involve testing and application of new technology, exploring of }\end{array}$ \\
\hline
\end{tabular}




\begin{tabular}{|c|c|}
\hline & $\begin{array}{l}\text { potential markets among others. The outcome can be social learning and } \\
\text { generated information can inform how a new technology triggers reaction of } \\
\text { different stakeholder groups like consumers, policy makers, competitors and } \\
\text { suppliers (Hekkert and Negro, 2009). }\end{array}$ \\
\hline $\begin{array}{l}\text { F2: Knowledge } \\
\text { development }\end{array}$ & $\begin{array}{l}\text { Involves activities around the new technology that denote learning that can } \\
\text { come about through research and development ( } R \text { \& D) or through practical } \\
\text { ways (knowledge about markets, networks and users). In a system, a need } \\
\text { may arise for adaptation in response to social-technical and market related } \\
\text { issues about the new technology. }\end{array}$ \\
\hline $\begin{array}{l}\text { F3: Knowledge } \\
\text { diffusion }\end{array}$ & $\begin{array}{l}\text { Involves activities that primarily lead to exchange of different forms of } \\
\text { knowledge/information among actors and is enhanced within networks. } \\
\text { Learning consequently occurs when actors use knowledge and interact. It can } \\
\text { lead to re-orientation of R\&D agendas. }\end{array}$ \\
\hline $\begin{array}{l}\text { F4: Guidance of the } \\
\text { search }\end{array}$ & $\begin{array}{l}\text { Involves activities that influence the attitude of actors and positive outlook } \\
\text { about a new technology. This may subsequently lead to persuasion to engage } \\
\text { or invest in a given TIS and may enhance legitimization of a technology. }\end{array}$ \\
\hline F5: Market formation & $\begin{array}{l}\text { New technologies encounter competition with incumbent technological } \\
\text { regimes resistant to change. This process therefore involves activities geared } \\
\text { towards establishment of new niche markets where new technologies are } \\
\text { appealing and may potentially grow. Policy support to such niches includes } \\
\text { tax regimes, guaranteed consumption quotas, environmental standards and } \\
\text { favorable procurement policies (Hekkert and Negro 2009; Bergek et al. } \\
\text { 2008). }\end{array}$ \\
\hline $\begin{array}{l}\text { F6: Resource } \\
\text { mobilization }\end{array}$ & $\begin{array}{l}\text { Involves activities coalesced around mobilizing of physical, human and } \\
\text { financial resources to support the development of the emerging technological } \\
\text { ecosystem. Complementary resources to support this process include } \\
\text { products, services and network infrastructure (Hekkert et al. 2007; Bergek et } \\
\text { al. 2008). }\end{array}$ \\
\hline $\begin{array}{l}\text { F7: Creation of } \\
\text { legitimacy }\end{array}$ & $\begin{array}{l}\text { Involves activities to situate or establish a new technology within a dominant } \\
\text { existing system or regime that is resistant to change. These include advocacy } \\
\text { efforts by different stakeholder lobby groups for resources or favorable } \\
\text { policies (Hekkert et al. 2007). }\end{array}$ \\
\hline
\end{tabular}

The TIS approach has been applied mainly in advanced countries particularly in interrogating the dynamics of renewable technologies (Bergek et al. 2008; Hekkert and Negro 2009; Negro and Hekkert 2008). In the digital innovation, TIS application has been reported only in Swedish mobile data (Lindmark and Rickne 2005; quoted in Bergek et al. 2008). The case studies from which inferences are made include Swedish renewable technologies and wind turbines in Germany, largely developed and diffused in these respective advanced but localized contexts. It is important to note that renewable energies being adopted in the African context tend to define TISs that have a greater focus on adoption and diffusion of technologies imported from abroad (Lema et al. 2018). Perhaps in acknowledgement of the applicability of the framework in diverse contexts, scholars interested in the emerging renewable energies in Africa have used this framework with useful insights (Tigabu 2017; Kebede and Mitsufuji 2016). Consequently, an important question relates to whether TIS is universally applicable to both developed and emerging contexts irrespective of stage of evolution of technology in question. This paper does not directly address this question. The TIS framework has not been applied on a digital technology from an emerging country context. This paper draws insights from this framework to analyze and map the performance of M-Pesa thereby describing empirically the functional factors attributed to the success narrative that has been advanced over the years. The framework further allows for identification of key policy issues for necessary policy and practice intervention (Bergek et al. 2008; Jacobsson and Bergek 2006). 


\subsection{Data collection}

This study undertook an in-depth analysis of a successful digital finance innovation case. Some insights into the case study application are drawn from Yin (2009). The analysis pays specific attention to some of the factors that distinguish the case study as a successful innovation through a critical review of events and activities as they unfolded between 2005 and 2018. Historical events and activities are tracked through analysis of secondary materials (literature, media reports and gray materials) complemented by experiences observed and encountered (real time transactions on a daily basis in money payments and remittances as an M-Pesa user) and with the service providers (M-Pesa agents \& supermarkets). The study is further supported by interviews with selected actors in the digital finance sector undertaken between October 2017 and May 2018 (Table 2). Validation of the findings was also done in a group discussion setting involving participants attending two events. The "the empire of the digital: views from South Asia and East Africa" workshop was held on 22 May 2018 in Nairobi, Kenya. The panel session on "Innovation for inclusive and sustainable industrialization" on 25 June 2018 in Johannesburg, South Africa. Valuable comments received during the two workshops informed further analysis and final write up.

Table 2: Research participants

\begin{tabular}{||l|l|l|l|l||}
\hline & Categories of participants & Location & Date & No. \\
\hline 1 & M-Pesa agents (observation \& interviews) & Urban market, Nairobi & Oct 17 - May 18 & 3 \\
\hline 2 & Supermarkets (tellers) & $\begin{array}{l}\text { Urban and peri-urban } \\
\text { Kiambu \& Nairobi }\end{array}$ & Oct 17 - May 18 & 3 \\
\hline 3 & Individual M-Pesa users & Nairobi & April 18 & 2 \\
\hline 4 & $\begin{array}{l}\text { Researchers (development studies, } \\
\text { innovation) }\end{array}$ & $\begin{array}{l}\text { Nairobi } \\
\text { Johannesburg }\end{array}$ & $\begin{array}{l}\text { 22 May 18 } \\
\text { 25 June 18 }\end{array}$ & $20+15=35$ \\
\hline 5 & Safaricom staff & Kigali & 5 June 18 & 1 \\
\hline & Total & & $\mathbf{4 5}$ \\
\hline
\end{tabular}

The overall analysis is applied at the level of technological innovation system (TIS) whereby events and activities contribute significantly to the buildup of system functions presented in the subsequent sections. Further, some particular attention is paid to relevant theories in diffusion of innovation literature. The paper draws learning lessons that can inform policy and practice recommendations for a successful and sustained adoption of digital finance innovations in emerging economies like Kenya.

\section{Case analysis and discussion: adoption and diffusion of M-Pesa}

\subsection{Mobile market and mobile money service in Kenya}

The tremendous growth of mobile money service in Kenya is synonymous with unprecedented penetration rate and adoption of mobile phones which may be attributed to a conducive ICT infrastructure (Tuwei and Tully 2017; Heeks 2011). At the macro level, the Information Technology Agreement (ITA) of the World Trade Organization (WTO), implemented in 1996, and expanded in 2015, may have played an indirect role too. The ITA has also enhanced a conducive ICT infrastructure for diffusion of digital innovations in developing countries including Kenya (Ezell and Wu 2017). A remark made by the then Cabinet Secretary, Foreign Affairs, when Kenya hosted the WTO meeting in Nairobi in 2015, seems to support this view (Murimi 2015). Subsequently, the telecommunication sector reforms advanced by the government in early 2000's may have encouraged competition among several mobile operators. This competition led to a drop in cost of mobile phone services and to date, the 
number of mobile subscribers has grown tremendously (CA 2018). Despite the telecommunication reforms, Kenya's mobile market has a high Herfindahl-Hirschman Index (HHI) indicating low levels of competition between mobile network operators - MNOs (Telecommunication Competition Market Study report, 2018). Among the major operators, Safaricom has maintained a high share of subscribers (CA, 2018) but this dominance is changing rapidly following the increased competition amongst operators that has been spurred by conducive mobile money ecosystem in Kenya (Sunday 2018; CA 2018).

M-Pesa ('M' for mobile and Pesa is Swahili for money) is a mobile-phone based money transfer and micro-financing service launched in Kenya in 2007 by Vodafone UK and Safaricom, the largest telecommunication company in Kenya. The initial technological idea was designed by Vodafone in UK before piloting commenced in 2005 (Hughes and Lonie 2007). It is credited for enhancing financial inclusion among a significant population of the unbanked in Kenya. Ten years after its market launch in 2007, the M-Pesa platform has evolved tremendously in design to allow different functionalities that facilitate access to multiple services to about 46.6 million of adult Kenyans who have mobile accounts (as of $30^{\text {th }}$ September 2018 according to CA, 2018:8). The mobile money transactions models include both mobile payment and mobile banking, signifying the changing consumer behavior (Etim 2014; Brundel \& Azrioual 2018). The value of financial transactions conducted through this platform is phenomenal. For instance by March 2016, KSh. 5.29 trillion (equivalent to 85\% of the country's GDP) was transacted. For a comparison of transactions across networks between June and September 2018, see Table 3. The different transactions are facilitated by a network of agents spread out across the country and within East Africa (according to CA 2018, the current figure stands at 162,800 agents as per $30^{\text {th }}$ September 2018).

There are a number of studies that have been undertaken to explore why M-Pesa has been successful. These have focused mainly on user side and technology supply side, primarily at the macro level. Some scholars seek to understand how M-Pesa meets developmental and financial inclusion goals and the surrounding technology transfer ecosystem (Foster and Heeks 2013a, 2013b; Onsongo and Schot 2017; Meagher 2018; Lashitew, Bals, and van Tulder 2018). Foster and Heeks (2013a) argue that successful piloting and diffusion of M-Pesa was shaped by the poor consumers' context. They distinguish the different but interactive roles played by different innovation actors in the innovation process. These scholars may be credited for exposing the interactive learning emerging from both product and process oriented innovations that characterize M-Pesa. Onsongo and Schot (2017) argue that the rapid growth of M-Pesa can be explained by the socio-technical system transition orchestrated by Kenyan financial services. The current study attempts to explore the micro level dynamics (for instance changing innovation preferences by individual consumers) associated with diffusion of financial innovations.

\subsection{Mapping the system functions of M-Pesa TIS}

The analysis is focused on a technological knowledge field (digital or mobile money transfer), while M-Pesa mobile money transfer platform defines the boundaries of the system. It has a global outlook although localized in the Kenyan context. An analysis and matching of historical events prior to and after the launch of M-Pesa between 2005 and 2018 based on secondary and primary data presents emergence of system functions (Table 2).

\subsubsection{Function 1 (F1): Entrepreneurial activities}

This entails trials of innovative experiments involving a new technology by a wide range of stakeholders with interests in entrepreneurship. The M-Pesa digital money service was spurred 
by Vodafone UK interest in provision of a financial service to the marginalized poor (Mas and Radcliffe 2010). The initial technological idea was therefore designed to provide a mobile enabled loan repayment service (Hughes and Lonie 2007). Vodafone later entered into a partnership with Safaricom, Faulu Kenya, a Micro-finance institute (MFI) and Commercial Bank of Africa (CBA) for the technological product testing and subsequent launching purposes. Following experimentation of several products, an initial money transfer platform was eventually designed to allow customers to receive and re-pay loans using a mobile handset (Hughes and Lonie 2007:68). The product went through various modifications commensurate with consumers' preferences before the final product was eventually launched in March 2007 (Foster and Heeks 2013a; Hughes and Lonie 2007). Safaricom has since opened up the application programming interfaces (APIs) to third parties including banks and other service providers. Consequently, this has progressively permitted expansion of applications and ventures that are M-Pesa integrated (Appendix 1). Safaricom continues to undertake product innovations that are market driven which include both mobile payment and mobile banking services. This is evidence of optimization of technology aligned to users' needs (Brundel \& Azrioual 2018; Planko et al. 2017). The critical coordination role played by the lead firms (Vodafone and Safaricom) in entrepreneurial experimentation at the formative period of uncertainty has been acknowledged by other scholars (Hughes and Lonie 2007; Lashitew, Bals, and van Tulder 2018).

\subsubsection{Functions $2 \& 3$ (F2 \& F3): Knowledge development and diffusion}

M-Pesa was spurred by R \& D oriented technical innovation developed by Vodafone UK (Hughes and Lonie 2007) which further underwent re-orientation following product modifications and expansions in response to customers' needs (Foster and Heeks 2013a). By mapping events and activities supporting these two functions, Fig. 1 below demonstrates co-evolution of technical knowledge and practical knowledge. This is a significant indicator of M-Pesa knowledge development and diffusion trajectory across scales. Foster and Heeks (2013a) describe this knowledge co-evolution process in terms of technological idea diffusing downstream and further upstream when Safaricom accepted to test M-Pesa viability in the Kenyan context. The upstream trend is characterized by consolidation and expansion of user driven knowledge base in the process adaptation. Learning and building of capabilities takes place when actors use knowledge and interact (Lema et al. 2018). In the case of M-Pesa, learning contributed to re-orientation of the initial $\mathrm{R} \& \mathrm{D}$ agenda to embrace process innovation 
and subsequent expansion of the service which is an important indicator of a functional system (Hekkert et al. 2007; Kebede and Mitsufuji 2016; Foster and Heeks 2013a).

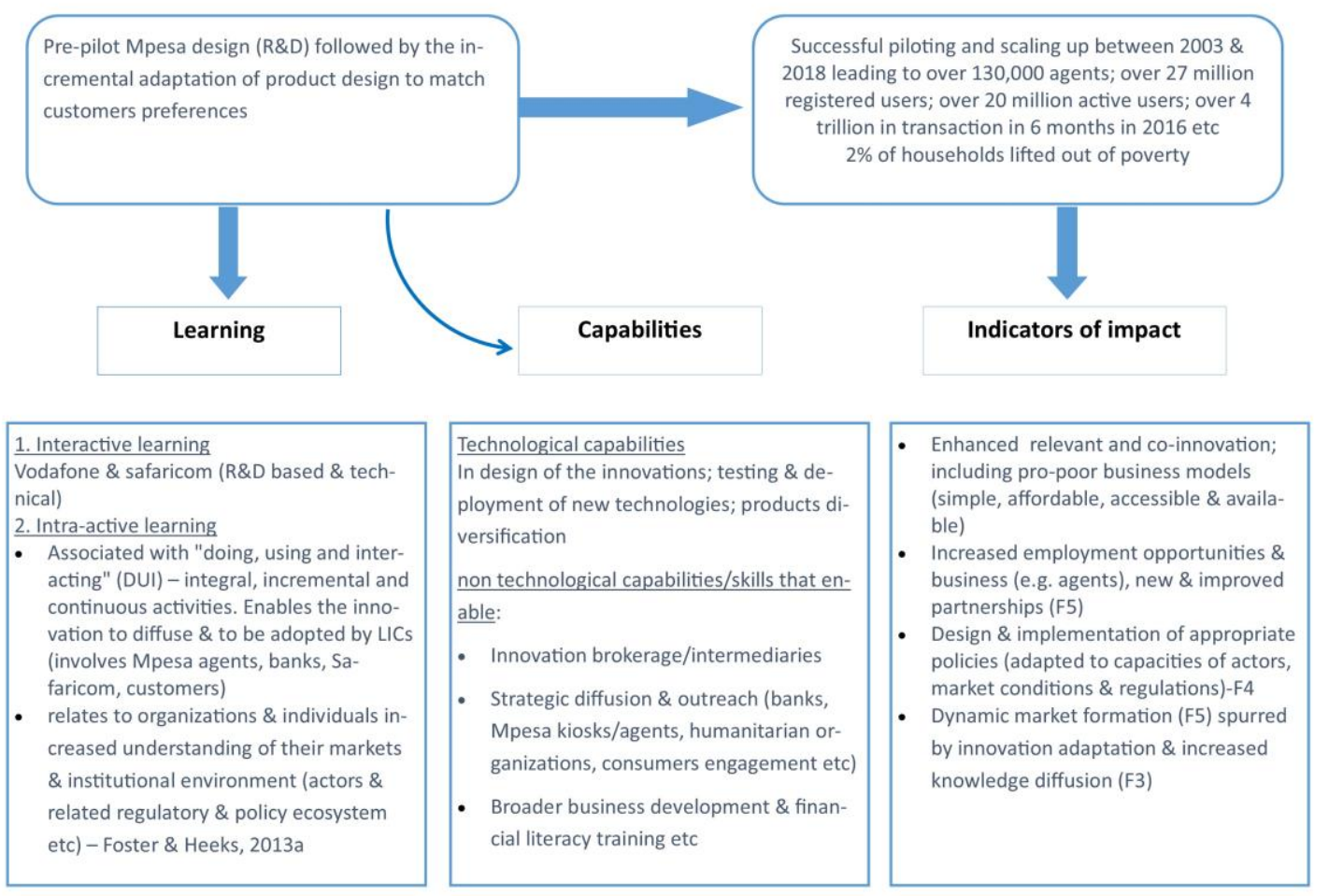

Figure 1: Dynamics of M-Pesa knowledge development and diffusion infrastructure

Fig. 1 exposes R\&D oriented events and activities that qualify learning and technical capabilities. However, more prevalent is the DUI learning and non-technical skills resulting from integration of multiple actors and expansion of the M-Pesa service (Lundvall 1992).

\subsubsection{Function 4 (F. 4): Guidance of the search}

The lead firms (Vodafone and Safaricom) played a key stewardship role in technological development and diffusion (Foster and Heeks 2013a). The firms further provided technological expertise to the government in the search for requisite digital finance policies that have promoted a healthy competition and collaboration amongst Kenya's digital finance actors (Muthiora 2015). According to Bergek et al. (2008:415), this function can be measured using qualitative factors.

i) Ability of specific actors to proactively steer the innovation process towards particular pro-innovation goals to achieve multiple purposes including legitimization acquisition.

- Safaricom (lead firm) enlisted the interests of different stakeholders in a risky and uncertain venture that led to the establishment of a vibrant local network of actors.

- The regulatory pressure: Central Bank of Kenya (CBK) leadership in creation of a mobile money regulatory infrastructure.

ii) Beliefs in the digital money service growth potential. This was perpetuated by Safaricom and the growing network of entrepreneurs. 
iii) Articulation of demand by leading customers in the digital innovation particularly in mobile banking. This can be attributed to the sustained learning built around expansion of M-Pesa products.

In line with Bergek et al. (2008: 415), the government and lead firm were instrumental in spearheading the search for appropriate technologies and products as well as guiding in the establishment of a requisite policy environment. However, the dynamic coordination role played by the two players in the M-Pesa case is not explicitly articulated in the TIS literature.

\subsubsection{Function (F. 5): Market formation}

The growth of M-Pesa service in terms of volumes of transaction and subscribers has outshined other money mobile services (Table 3). The potential for a market to establish and expand especially when uncertainty prevails can be attributed to many factors. In the case of M-Pesa, market expansion is characterized by the establishment and subsequent rapid expansion of network of agents to serve the consumers' varying mobile money transaction needs (Foster and Heeks 2013a). The total number of M-Pesa agents across the country stands at 162,800 as of September 2018 (Table 3). Another indicator of market expansion is the revenue from the service that grew by $27.2 \%$ from KSh. 32.63 million in 2015 to KSh. 41.50 million in 2016 (Safaricom 2016). The number of customers has also been growing and as of September, 2016, there were 24.8 million registered customers and 17.6 million active users. Following the expansion of M-Pesa functionalities, other successful M-Pesa integrated innovations have been launched as partnerships with financial institutions and other service providers (Appendix 1).

Table 3: Mobile Money Transfer Service: M-Pesa relative to other operators (CA, 2018:11)

\begin{tabular}{|l|c|c|c|c|c|c|c|}
\hline $\begin{array}{l}\text { Operator } \\
\text { Indicator }\end{array}$ & Agents & $\begin{array}{c}\text { Active } \\
\text { Subscriptions }\end{array}$ & $\begin{array}{l}\text { No. of } \\
\text { Transactions }\end{array}$ & $\begin{array}{c}\text { Value of } \\
\text { Transactions } \\
\text { (Kshs) }\end{array}$ & $\begin{array}{c}\text { No. of M- } \\
\text { Commerce } \\
\text { Transactions }\end{array}$ & $\begin{array}{c}\text { Value of M- } \\
\text { Commerce } \\
\text { Transactions } \\
\text { (Ksh.) }\end{array}$ & $\begin{array}{c}\text { P2P Transfers } \\
\text { (Ksh.) }\end{array}$ \\
\hline M-Pesa & 162,800 & $24,206,341$ & $575,660,251$ & $1,585,729,101,317$ & $430,190,383$ & $1,203,392,814,229$ & $590,345,941,145$ \\
\hline Airtel Money & 27,267 & $3,434,843$ & $4,628,370$ & $1,153,142,919$ & $3,042,680$ & $2,220,280,505$ & $1,213,897,584$ \\
\hline $\begin{array}{l}\text { Equitel } \\
\text { Money }\end{array}$ & - & $1,992,150$ & $149,463,508$ & $439,188,528,611$ & $92,748,695$ & $347,176,769,388$ & $125,981,207,772$ \\
\hline T-Kash & 21,538 & 59,933 & 104,833 & $197,106,156$ & $1,009,427$ & $85,656,719$ & $12,820,830$ \\
\hline Mobile Pay & 6,890 & 92,122 & 354,565 & $1,379,068,293$ & - & - & $729,012,558$ \\
\hline Total & $\mathbf{2 1 8 , 4 9 5}$ & $\mathbf{2 9 , 7 8 5 , 3 8 9}$ & $\mathbf{7 3 0 , 2 1 1 , 5 2 7}$ & $\mathbf{2 , 0 2 7 , 6 4 6 , 9 4 7 , 2 9 6}$ & $\mathbf{5 2 6 , 9 9 1 , 1 8 5}$ & $\mathbf{1 , 5 5 2 , 8 7 5 , 5 2 0 , 8 4 1}$ & $\mathbf{7 1 8 , 2 8 2 , 8 7 9 , 8 8 9}$ \\
\hline \multicolumn{2}{|c|}{ Source: $\mathbf{C A , \text { Operators' Returns }}$} & & & & & \\
\hline
\end{tabular}

M-Pesa diffusion path has demonstrated the critical role played by Safaricom and the expanded network of agents in raising M-Pesa user awareness and stimulating change in user behavior. This stimulated demand and a market for M-Pesa products. This implies that private sector and entrepreneurs play an important role in diffusion of technologies through building of relevant capacities (Ibid). Diffusion theories have explained the lengthy process of persuasion before users adopt a new technology. The role of public and private sector in stimulating market formation in this regard is acknowledged in literature (Bergek et al. 2008; Jacobsson and Bergek 2011). In addition, institutional change that has to do with technology user behavior and preference is a critical role that entrepreneurs can play as system builders to stimulate market formation (Planko et al. 2017).

\subsubsection{Function 6 (F.6): Resource mobilization}


The establishment of a successful TIS is attributed to mobilization of resources that include financial, competence and human capital (Lundvall 1992). M-Pesa journey to success commenced in 2003 when Vodafone-UK obtained a matching grant from Department for International Development (DFID), UK. This initial capital was instrumental in creating a technology buy-in, initial awareness creation and capabilities building amongst different value chain actors. It was also crucial to leveraging of more funds for subsequent piloting of products, creation and expansion of relevant partnerships and collection of relevant context specific information. Safaricom's promotion of its corporate image and expanded partnerships have helped to leverage resources in pursuit of consolidated efforts aimed at enhancing legitimization of M-Pesa products more generally (Lashitew, Bals, and van Tulder 2018).

\subsubsection{Function (F.7): Legitimation}

The M-Pesa legitimization acquisition has been progressive since the the formative piloting stage to date and this is expected to continue throughout the diffusion and expansion phases. Legitimization entails a new technology receiving requisite social acceptance and be regulatory and policy compliant (Bergek et al. 2008). This process can take different dimensions and may involve advocacy efforts for enhancing support or rejection of the technology by different stakeholders. Specific activities can be tracked that signify M-Pesa legitimization efforts.

\subsubsection{Sustained efforts to enhance financial inclusion and demonstrate social impact}

Safaricom adopted a strategic promotion of the M-Pesa service for social acceptance, trust building and increased sales using its already trusted brand name. This was characterized by awareness campaigns and provisions of incentives to register as users of the product. Further, Safaricom has successfully integrated large number of low and middle income consumers (LMICs) actors into the M-Pesa design and delivery chain through a process of experimentation and adaptation (Foster and Heeks 2013a). The M-Pesa service has provided a digital money transfer platform to many actors who would otherwise have been locked out by a number of logistical factors including technicalities, cost and regulation (Jacobsson and Bergek 2004; Muthiora 2015; Sunday 2018). For instance, improved functionalities of M-Pesa have enhanced new business models thus integrating local and international banks, supermarkets and other service providers (Appendix 1). There is fear that this expansion might exclude the low income consumers (LICs) who were the initial intended beneficiaries of M-Pesa early product (personal communication, development studies researcher, 22 May 2018). This aspect is not explored in this paper but it certainly echoes sentiments of other scholars (Foster and Heeks 2013a; Meagher 2018).

\subsubsection{A collaborative approach to creation of an enabling mobile money regulatory ecosystem}

M-Pesa innovation idea was conceived under a regulatory vacuum since the CBK Act of Parliament did not have a provision for regulation of non-banks (Hughes and Lonie 2007; Muthiora 2015). Muthiora (2015) chronicles in details the process of establishing a regulatory infrastructure for digital finance sector. This was prompted by an application in 2005 to CBK by Commercial Bank of Africa (CBA), Safaricom Limited and Vodafone group to authorize M-Pesa roll out. Discussions pioneered by CBK commenced between Safaricom (industry) and relevant government authorities (Ministry of Information and Communication, Ministry of Finance, CBK and CCK). This process was industry inspired and therefore CBK benefited from the technical guidance provided by Safaricom. In February 2007, CBK allowed Safaricom to operate both as a telecommunication company and a mobile banking company pending enactment of relevant legislation. Consequently, the National Payment System (NPS) Act was 
passed in 2011 but became law in March 2014. Later on, the NPS Regulations of 2014 were officially issued thereby permitting both banks and non-banks to provide money services (Muthiora 2015:19).

\subsubsection{Ability to counter controversies}

As expected, M-Pesa introduction attracted suspicion surrounding the service's economic and social impact. The eminent institutional and organizational changes threatened the interests of Kenya Bankers Association (KBA) which was in the opinion that M-Pesa should not be exempted from rules regulating commercial banks. After an audit commissioned by the CBK and National Treasury, M-Pesa was permitted to operate (Okoth 2009). The critical role played by $\mathrm{CBK}$ as a purportedly neutral broker to manage the controversies emanating from the banks is evident. Controversies have also been experienced from other mobile money operators whose products have not been quite successful, challenging dominance of M-Pesa in the market (Reuters 2018; Mumo 2017a; Table 3). It is worth noting that at the early phase of M-Pesa's introduction into the market, Safaricom did not allow M-Pesa agents to serve any other mobile money service provider. Safaricom has made unsuccessful efforts to keep the status quo. Consequently, in an effort to promote fair competition among different service providers, telecommunication reforms have made it illegal for operators to demand that their agents remain exclusive to their products.

Further, there have been unsuccessful efforts to split M-Pesa from Safaricom as a move to make the telecommunication market more competitive (Reuters 2018; Mumo 2017a). Arguably, there is a critical role for the government to enhance competiveness in the digital finance innovation while at the same time enhance requisite regulation (Bergek et al. 2008; Jacobsson and Bergek 2011). This may be one way to ensure transparency and trust that could perpetuate internal and external legitimacy.

\subsubsection{Assessing M-Pesa phases of development and diffusion}

This section combines both the mapping of events as they evolved between 2005 and 2018 (Appendix 1) and associated system functions build-up demonstrated in the preceding section and summarized in section 3.2.7.

Bergek et al. (2008) identifies two phases of a TIS, the formative phase and growth phase. Hekkert et al. (2011) on the other hand adopt the "S-curve" of technology diffusion and use to describe different growth phases. These include pre-development phase, development phase, take-off phase, acceleration phase and stabilization phase. Based on an approach that combines both classifications, three phases emerge from the analysis of M-Pesa case.

\subsubsection{Piloting or formative phase}

Hughes and Lonie (2007) give a detailed account of the piloting phase characterized by non-technological related undertakings that shaped the ecosystem that made the launch of M-Pesa possible. Muthiora (2015) on the other hand chronicles the evolution of the mobile money policies in Kenya that was triggered by M-Pesa. Thus, a review of the available resources during this period of uncertainty helps us to understand the dynamics involved in charting a roadmap for deployment of M-Pesa through multiple entrepreneurial activities and strategic guidance of search.

\subsubsection{Post launch growth and acceleration phase}

This is the most dynamic period of M-Pesa diffusion and adoption curve. After the pilot phase, the product was perceived to be ready technically and commercially as well as profitable to the 
developers and users. In addition, it could meet the needs of majority Kenyans especially the LICs. The launch eventually took place in March 2007 and over ten years of M-Pesa service in the market have recorded tremendous growth (Table 3; Appendix 1).

\subsubsection{Expansion phase}

The M-Pesa money service platform has evolved over the years to include other values, ventures and functionalities (Appendix 1). This is an interesting phase that comes before standardization or saturation phase. It is characterized by the following features;

- Consolidation of the market base. This includes ensuring a) the established market targeting LICs and medium income consumers (MICs) is sustained b) the network of agents is strengthened and c) partnerships are expanded to consolidate revenues/profits.

- Expansion through diversification of M-Pesa integrated products.

- Continued endeavors to consolidate and sustain acquisition of legitimization. This is triggered by different factors. These include; political economy surrounding M-Pesa (Juma 2017; Mumo 2017a, 2017c), quest to demonstrate social impact lined to M-Pesa (Lashitew, Bals, and van Tulder 2018), implementation (or review) of telecommunication regulations (Reuters 2018) among other unforeseen market factors. A major milestone in this regard is the e-wallet interoperability across networks launched by Safaricom, Telecom and Airtel (Sunday 2018).

\subsubsection{The system functions build up}

According to Hekkert et al. (2007), a system function emerges when an event or activity that matches the function is noticed. It is therefore possible to develop a functional pattern observed between 2005 and 2018 as depicted in Fig. 2 that further illustrates reinforcing cycles within the M-Pesa TIS. 


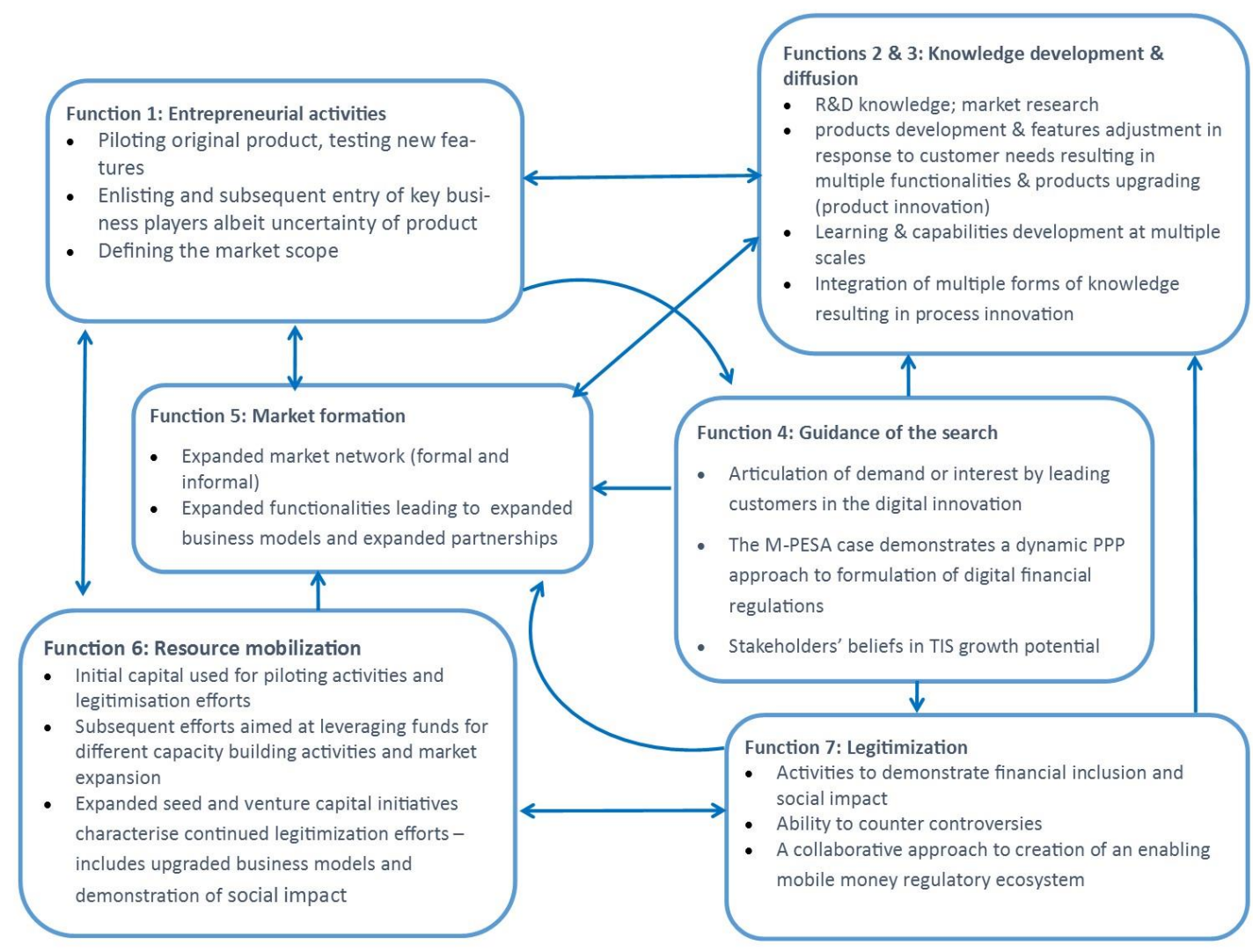

Figure 2: The Functional systems of M-Pesa (analysis)

All the events and activities around M-Pesa TIS could be aligned to the seven system functions proposed by Hekkert et al. (2007) and Bergek et al. (2008). These functions interact and reinforce each other thus providing evidence of how build-up of system functions has influenced to date the development and diffusion of M-Pesa in Kenya. The M-Pesa successful diffusion story is extensively supported by a number of major functions (F1, F 2\&3, F5 \& F7), while Functions 4 and 6 may be perceived to be reinforcing these main functions. Consequently, the analysis points towards three key factors that have played a role in stimulating the functional aspects of M-Pesa.

First, the leadership and coordination role played by the lead industry players particularly Safaricom stimulated all the seven functions. M-Pesa has revolutionized mobile money transfer leading to emerging business oriented production paradigm (Appendix 1). This can be attributed to the critical stewardship role of Safaricom in strategically designing M-Pesa platform to be more inclusive. Arguably, this has resulted in increased business opportunities perpetuated through an elaborate network of partners (F5) and significant milestones in legitimization acquisition (F7). Second, the interlinked network of entrepreneurs (e.g. M-Pesa agents, banks and other service providers) have contributed significantly to generation of knowledge development and diffusion (F2 \& F3). Notably, M-Pesa system functions build-up can be attributed to learning by doing, using and interaction (DUI) emanating from this expanded network of entrepreneurs (Foster and Heeks 2013a). Third, the pro-innovation facilitative and boundary-spanning role played by the government through CBK and Communication Authority of Kenya (CAK). The government has significantly contributed to the sustained legitimization acquisition process $(\mathrm{F} 7)$. 


\subsubsection{Identifying inducement and blocking mechanisms}

In recent studies focusing on renewable technologies, emerging TISs have been found to have weak functional dynamics (Tigabu, 2017; Kebede and Mitsufuji 2016).This is attributed to a number of blocking mechanisms which may be internal and external to the system. Some of these can be institutional alignment failure, poor networks, underdeveloped capabilities that ultimately affect the other functions (Bergek et al. 2008). This consequently affects attainment of advanced functionality of a system. On the other hand a system may have inducement mechanisms that support the growth and diffusion of a technology. In the case of M-Pesa, blocking mechanisms were experienced at the formative phase in form of an anti-technology lobby group in the banking sector that almost killed the M-Pesa initiative (Okoth 2009) and a regulatory vacuum (Muthiora 2015). The latter however reversed to become an inducement mechanism promoting market formation and legitimization when the relevant regulatory policies were approved by parliament. Other inducement mechanisms include the belief in the upward growth of ICT sector in Kenya and in particular mobile money transfer (FinAccess National Survey 2009; Heeks 2011; CA 2018).

The over ten years of learning and local capabilities building surrounding M-Pesa service upgrading and re-design have contributed to rapid market expansion. This is an inducement mechanism upon which learning lessons can be drawn for policy and practice. Arguably, this can become a blocking mechanism if strategies for inclusive and competitive playing ground for innovators are not devised and sustained.

\subsubsection{Identifying key policy issues}

Policy issues should be informed by mechanisms that block or induce diffusion or adoption of an innovation. The intention is to provide policy interventions that target "system failure" rather than market or structural failure (Bergek et al. 2008). In the M-Pesa case, the inducement mechanisms supersede blocking mechanisms, perhaps the reason why the TIS has been quite successful. A few policy issues are recommended which largely re-enforce the inducement mechanisms more generally.

i. Support learning and inclusive capabilities for sustained demand articulation. This help to maximise productive adoption of M-Pesa integrated advanced features and functionalities. These should target both systems developers (entrepreneurs, innovators) and users (intermediaries/agents, LICs and MICs).

ii. Sustained leveraging of resources. This is critical for sustained learning, capabilities building and market expansion as well as legitimization efforts aimed at increasing social impact that is evidence-based.

iii. Balanced pro-innovation process: Government support is crucial at formative phase of nascent emerging innovations as evidenced by M-Pesa case. However, there is need for balanced regulations that support innovation as well as encourage competition among interested entrepreneurs and innovators. Further, the role of lead firm/s must be clearly defined to enhance legitimacy. Bergek et al. (2008) and Jacobsson and Bergek (2011) note that government through policies, including tax regimes generates demand for products. However, when private and public sector combine efforts, fair and feasible business models are likely to be generated (Planko et al. 2017).

\section{Conclusion}


This paper provides an empirical verification of the systemic performance of M-Pesa functions and factors that influence the process as presented by Bergek et al. (2008) and other proponents of the TIS framework. The analysis finds that key functions that characterize the M-Pesa rapid diffusion in Kenya include; entrepreneurial experimentation (F1), knowledge generation and diffusion (F2\&F3), market formation (F5) and legitimization (F7). From a theoretical perspective, the study finds that TIS framework can be applied in explaining adaptation and diffusion of a foreign product in a developing economy context. Despite the relevance of TIS framework, there are certain factors about M-Pesa that require critical thought in relation to how they contribute to the functioning of this TIS. Our study notes that although the initial idea or early $\mathrm{R} \& \mathrm{D}$ innovation originated from abroad (UK), it had to undergo numerous adaptations in response to consumers' preferences (this is still product innovation but localized in the local context). This was accompanied by dynamic process innovation as different stakeholders' interacted thereby generating significant learning and local capabilities. Scholars in development studies have demonstrated the relevance of learning and local capabilities in the transfer of international technologies (Lema et al. 2018). Further, the analysis suggests the value of tasks' coordination at different scales by specific champion actors. The TIS framework acknowledges the importance of coordination in relation to provision of specialized goods and services to enhance functioning of an innovation system (Bergek et al. 2008). However, the dynamic coordination role performed by Safaricom and the government at different times within M-Pesa diffusion curve cannot be explicitly accounted for by the TIS framework. The paper identifies key policy issues and policy goals based on what qualify as mechanisms that block or induce diffusion or adoption of a new innovation. Arguably, whether M-Pesa case can be replicated elsewhere is a matter of further research and lessons drawn from this study can certainly provide useful insights.

\section{Further research}

This paper largely focused on the factors linked to diffusion and adoption of an emerging digital innovation from both user and supplier perspectives. The study revealed that there are more significant systemic but micro factors (as opposed to structural and market factors) that affect the user side. One interviewee, a development studies researcher, argued that micro and systemic factors at demand side (technology user) rather than supply side (technology developer) are more crucial for inclusive innovation policies. This echoes other scholars' views (Foster and Heeks 2013a; Meagher 2018) which implies that inclusion aspects of new innovations in emerging economies is an important research area. In relation to inclusion, a number of interviewees suggested further research to generate data around real impact of digital financial innovations for different levels of consumers. Another interviewee who is keen on system's approach to adoption of technologies suggested that policy interventions that target failure of specific functions at system level should embrace the complexity of a given system. He argued that application of the functional systems approach should therefore not ignore the role of market or structural failures in overall diffusion and adoption of emerging technologies. Another innovation scholar further downplayed the TIS framework and noted that the dynamic system functions are generally reinforcing the power of innovation system's framework to demonstrate the emergence of a local innovation system. All these unresolved issues form varying entry points for further research.

\section{Acknowledgments}


This work was supported by Oxford University under Africa Oxford (AfOx) Travel Grant number AfiOx-29.

\section{References}

Amal, A., T. Bhosale, and S. Mujumdar. 2014. "Diffusion of Innovation”. Slide presentation. Accessed 12 December 2018. http://www.slideshare.net/ animeshgupta583/diffusion-andadoption-of-innovation

Bara, A. 2016. "Diffusion and adoption of bank financial innovation in Zimbabwe: An external factor analysis". African Journal of Science, Technology, Innovation and Development, 8 (4): 357-368.

Bergek, A., S. Jacobsson, B. Carlsson, S. Lindmark, and A. Rickne. 2008. "Analyzing the Functional Dynamics of Technological Innovation Systems." A Scheme of Analysis Research Policy 37 (3): 407-429.

Brundel, C., and S. Azrioual. 2018. "The acceptance of mobile banking by organizations. An exploratory study on mobile banking and factors influencing its acceptance by organizations". Master Thesis, Business Administration. Jonkoping University. Jonkoping International Business School.

Communication Authority (CA) of Kenya. 2018. First Quarter Sector Statistics Report for the Financial Year 2018/2019 (July-September 2018). Accessed 19 December 2018. https://ca.go.ke/wp-content/uploads/2018/12/Sector-Statistics-Report-Q1-2018-2019.pdf

Etim, A. 2014. "Mobile banking and mobile money adoption for financial inclusion." Research in Business and Economics Journal (9), August, 2014.

http://www.aabri.com/manuscripts/141840.pdf

Ezell, S. J., and J. J. Wu. 2017. "How Joining the Information Technology Agreement Spurs Growth in Developing Nations." Washington, D.C. The Information Technology and Innovation Foundation (ITIF). Accessed 17 December 2018.

https://itif.org/publications/2017/05/22/how-joining-informationtechnology-agreement-spursgrowth-developing-nations

Foster, C., and R. Heeks. 2013a. "Innovation and scaling of ICT for the bottom-of-thepyramid ”. Journal of Information Technology 28: 296-315.

Foster, C., and R. Heeks. 2013b. "Analyzing policy for inclusive innovation. The mobile sector and and the base of the pyramid markets in Kenya". Innovation and Development 3 (1):103119.

FinAccess national survey. 2009. "Dynamics of Kenya's changing financial landscape". FSD Kenya and the Central Bank of Kenya. June.

Fu, X. 2014. "Diffusion of innovation in low income countries." Oxford University, UNCTAD, Geneva. http://www.tmd-oxford.org/content/diffusion-innovation-low-incomecountries-dilic. 
GSMA. 2015. "State of the industry report on mobile money". Groupe Speciale Mobile Association (GSMA) report. London, United Kingdom: Accessed 4 January 2018 http://www.gsma.com/mobilefordevelopment/wpcontent/uploads/2016/04/SOTIR_2015.pdf

GSMA. 2016. "Mobile money development tracker." Accessed 4 January 2018. https://www.gsma.com.

Heeks, R. 2011. "ICT and Economic Growth: Evidence from Kenya." ICTs for Development. 26 June 2011. Accessed 8 May 2017. http://ict4dblog.wordpress.com/2011/06/26/ict-andeconomic-growth-evidence-from-kenya/.

Hekkert, M., and S. Negro. 2009. "Functions of innovation systems as a framework to understand sustainable technological change: empirical evidence for earlier claims." Technological Forecasting and Social Change 76 (4): 584-594.

Hekkert, M., R. Suurs, S. Negro, R. Smits, and S. Kuhlmann. 2007. "Functions of innovation systems: a new approach for analyzing technological change". Technological Forecasting and Social Change, 74: 413-432.

Hekkert, M., S. Negro, G. Heimeriks, and R. Harmsen. 2011. "Technological Innovation System Analysis: A Manual for Analysts”. Accessed on 30 Jan. 2018.

http://www.innovation-system.net/wpcontent/uploads/2013/03/UU_02rapport_Technological_Innovation_System_Analysis.pdf

Hughes, N., and S. Lonie. 2007. "M-Pesa: mobile money for the "unbanked" turning cellphones into 24-hour tellers in Kenya." Innovations, 2 (1-2): 63-81.

Jacobsson, S., and A. Bergek. 2004. "Transforming the Energy Sector: the Evolution of Technological Systems in Renewable Energy Technology." Industrial and Corporate Change 13 (5): 815-849.

Jacobsson, S., and A. Bergek. 2006. "A framework for guiding policy-makers intervening in emerging innovation systems in 'catching-up' countries." The European Journal of Development Research 18 (4):687-707.

Jacobsson, S., and A. Bergek. 2011. "Innovation System Analyses and Sustainability Transitions: Contributions and Suggestions for Research." Environmental Innovation and Societal Transitions 1 (1): 41-57.

Juma, V. 2017. "Safaricom shields M-Pesa from Vodafone interests”. Business Daily. 25 August 2017. Accessed 5 April 2018. https://www.businessdailyafrica.com/corporate/companies/Safaricom-shields-M-Pesa-fromVodafone-interests/4003102-4070472-3asjsg/index.html

Kabanda, G. 2014. "Technology affordances and diffusion for mobile connectivity and applications in Zimbabwe." International Journal of Emerging Technology and Advanced Engineering 4 (6): 13-23. 
Kebede, K., and T. Mitsufuji. 2016. "Technological innovation system building for diffusion of renewable energy technology: A case of solar PV systems in Ethiopia". Technological Forecasting and Social Change. DOI: 10.1016/j.techfore.2016.08.018

Lashitew, A. A., L. Bals, and R. van Tulder. 2018. "Inclusive Business at the Base of the Pyramid: The Role of Embeddedness for Enabling Social Innovations." Journal of Business Ethics Bus Ethics. https://doi.org/10.1007/s10551-018-3995-y

Lema, R., R. Hanlin, U. E. Hansen, and C. Nzila. 2018. "Renewable electrification and local capability formation: Linkages and interactive learning." Energy Policy 117: 326-339.

Lindmark, S. and A. Rickne. 2005. "Dynamics and Functionality of the Swedish Mobile Internet Innovation System". Paper presented at the 16th European Regional Conference of the International Telecommunications Society (ITS), Porto.

Lundvall, B-Å. 1992. National Systems of Innovation. Towards a Theory of Innovation and Interactive Learning. Pinter Publishers: London.

Mas, I., and D. Radcliffe. 2010. "Mobile Payments go Viral: M-Pesa in Kenya." Bill \& Melinda Gates Foundation.

Meagher K. 2018. "Cannibalizing the Informal Economy: Frugal Innovation and Economic Inclusion in Africa". The European Journal of Development Research 30 (1): 17-33

Mumo, M. 2017a. "After 10 years success, M-Pesa treads uncertain path.” Business Daily. 8 March 2017. Accessed 4 April 2018. https://www.businessdailyafrica.com/corporate/After10-years-success--M-Pesa-treads-uncertain-path/539550-3841350-19fuouz/

Mumo, M. 2017b. "Safaricom owners get Ksh. 38 billion dividend windfall." Business Daily. 10 May 2017. Accessed 4 April 2018. https://www.businessdailyafrica.com/news/SafaricomSh38-billion-dividend-windfall/539546-3922052-1701jn/

Mumo, M. 2017c. "MP proposes stricter regulation of telecom companies." Business Daily. 2 March 2017. Accessed 4 April 2018. https://www.businessdailyafrica.com/news/Midiwosets-stage-for-law-to-break-up-Safaricom/539546-3834832-3eyj31/index.html

Murimi, M. 2015. "Kenya reaps big from WTO’s Information Technology Agreement." Statement by Foreign Affairs Cabinet Secretary Amina Mohammed. Citizen Digital time. 17 December 2015. Accessed 17 Dec 2018. https://citizentv.co.ke/news/kenya-reap-big-fromwtos-information-technology-agreement-109166/

Muthiora, B. 2015. "Enabling mobile money policies in Kenya. Fostering a digital financial revolution". Groupe Speciale Mobile Association (GSMA) report. Accessed 4 January 2018. https://www.gsma.com/mobilefordevelopment/wpcontent/uploads/2015/02/2015_MMU_Enabling-Mobile-Money-Policies-in-Kenya.pdf

Negro, S. and M. Hekkert. 2008. "Explaining the success of emerging technologies by innovation system functioning: the case of biomass digestion in Germany." Journal Technology Analysis \& Strategic Management 20 (4): 465-482. 
Ngugi B. 2017. "M-Pesa global transactions hit six billion in 2016." Business Daily. Sunday, 26 February 2017. Accessed on 4 April 2018.

https://www.businessdailyafrica.com/markets/MPesa-global-transactions-hit-six-billion2016/539552-3828662-7h9g3xz/index.html

Okoth J. 2009. "Regulator gives M-Pesa a clean bill of health", East African Standard, 27 January 2009. Accessed 18 Jan 2018.

https://www.standardmedia.co.ke/business/article/1144004990/regulator-gives-M-Pesa-aclean-bill-of-health

Onsongo, E. and J. Schot. 2017. "Inclusive Innovation and Rapid Sociotechnical Transitions: The Case of Mobile Money in Kenya". SPRU Working Paper Series (SWPS), 2017-07: 1-28. ISSN 2057-6668. http://dx.doi.org/10.2139/ssrn.2940184 on (Accessed on 4 Jan 2018).

Planko, J., J. Cramer, M. P. Hekkert, and M. M. H. Chappin. 2017. "Combining the technological innovation systems framework with the entrepreneurs' perspective on innovation.” Technology Analysis \& Strategic Management 29 (6): 614-625.

Reuters. 2018. "Communications Authority could force Safaricom to share agents' network." Business Daily. 29 May 2018. Accessed 30 May 2018.

https://www.businessdailyafrica.com/corporate/companies/C A-could-force-Safaricom-toshare-agents--network/4003102-4584988-13qgwhez/index.html

Rogers, E. M. 1983. Diffusion of innovations (3rd ed.) New York: Free Press.

Rogers, E. M. 2003. "Diffusion of innovations.” In An integrated approach to communication theory and research, edited by Don Stacks and Michael Salwen, 1962-1995. New York: Routledge.

Safaricom. 2016. "Widening our vision, sharpening our focus". Safaricom sustainability report 2016.

Safaricom. 2018. "M-Pesa Timeline. Celebrating Ten Years.” Accessed 4 Jan 2018. http://www.safaricom.co.ke/mpesa_timeline/timeline.html

Sunday, F. 2018. "You can now send or receive mobile money across networks." Business News. April 7. Accessed 5 May 2018).

https://www.standardmedia.co.ke/business/article/2001276005/operators-to-launch-moneytransfer-across-networks

Telecommunication Competition Market Study report. 2018. "Report commissioned by Communication Authority of Kenya". Accessed 15 April 2018. https://www.kictanet.or.ke/wp-content/uploads/2018/02/Telecommunication-CompetitionMarket-Study-in-Kenya-Abridged-version-Released-Feb-2018.pdf

Tigabu, D. A. 2017. "Analyzing the diffusion and adoption of renewable energy technologies in Africa: The functions of innovation systems perspective". African Journal of Science, Technology, Innovation and Development 0 (0):1-10. 
Tuwei, D., and M. Tully. 2017. "Producing communities and commodities: Safaricom and commercial nationalism in Kenya." Global Media and Communication 13 (1) 21-39.

Vodafone. 2016. "Vodafone M-Pesa reaches 25 million customers milestone." Accessed 5 April 2018). http://www.vodafone.com/content/index/media/vodafone-groupreleases/2016/mpesa-25million.html

Van der Boor, P., P. Oliveira, and F. Veloso. 2014. "Users as innovators in developing countries: The global sources of innovation and diffusion in mobile banking services." Research Policy 43 (9): 1594-1607.

World Bank. 2008. "Global Economic Prospects 2008: Technology Diffusion in the Developing World.” http://siteresources. worldbank.org/INTGEP2008/Resources/complete report.pdf

Yin, R.K. 2009. Case Study Research: Design and Methods. 4th ed. Sage Publications, Thousand Oaks, California.

\section{APPENDICES}

Appendix 1: Selected values, functionalities and ventures derived from M-PESA platform within 10 years (between 2007 and 2018)

\begin{tabular}{|c|c|}
\hline Type & Example \\
\hline $\begin{array}{l}\text { Cash payments } \\
\text { and transfers }\end{array}$ & $\begin{array}{l}\text {-M-Pesa money transfer among friends and relatives } \\
\text {-Lipa na M-Pesa for shopping and bill payments (from Oct 2010) } \\
\text {-M-Pesa outlets at fuel stations started with Caltex in } 2008 \\
\text {-Lipa Kodi for rent payment (since Aug 2013) } \\
\text {-Bank to M-Pesa transfers and vice versa } \\
\text {-International money transfer } \\
\text { • Western Union transfer from UK in Dec } 2008 \text {; } \\
\text { • Western Union international transfers from } 45 \text { countries from Mar } 2011 \\
\text { • Moneygram International transfers in over } 90 \text { countries from Nov } 2014 \\
\text { • M-Pesa \& Vodacom Tanzania -3/2015 } \\
\text { • MTN \& Vodacom for inbound and outbound money transfer across EA (since 12/2016) } \\
\text {-Lipa Karo for school fee payment support from Jan 2011. (About 4500 schools as of 2016). } \\
\text {-Bulk Payments (e.g. salaries) } \\
\text {-Utility payment - Electricity started with KPLC in April 2009); and M- Grundfos Lifelink project for } \\
\text { safe water access in Sep 2009. } \\
\text {-Okoa Stima -Kenya power bills payment by dialling *885\# from the mobile (04/2015). } \\
\text {-M-Ticketing (for concerts, events, galas and other sports since Dec 2010) } \\
\text {-M-Pesa Prepay Visa card. Started in Dec } 2011 \text { with I\&M Bank International Prepay Safari Visa Card } \\
\text { from } \\
\text {-PesaPoint for ATM money withdrawal services directly mobile (from 2008). } \\
\text {-M-Pesa services at commercial banks (started with Postbank in 2008). } \\
\text {-Trade in unit trusts and shares (started with Old Mutual Unit Trusts in 2008) } \\
\text {-E-Citizen platform for payment of Government of Kenya services using paybill number 206206 (April } \\
\text { 2015) } \\
\text {-Real-time settlement (RTS) -17 commercial banks boarded for the RTS service (07/2015) }\end{array}$ \\
\hline $\begin{array}{l}\text { Microfinance } \\
\text { services }\end{array}$ & $\begin{array}{l}\text { Housing Finance mortgage financing with Housing Finance (since 2008). } \\
\text { SMEP - Small and Micro Enterprise Programme in May } 2009 \\
\text { Equity Bank - M-Kesho (from May 2010) } \\
\text { M-Shwari (since Nov 2012) } \\
\text { Kenya Commercial Bank (KCB). Started with M-Pesa agents' access to E-float from May } 2009 . \\
\text { M-Akiba (allows buying Central Bank bonds since 2015) }\end{array}$ \\
\hline
\end{tabular}




\begin{tabular}{|c|c|}
\hline $\begin{array}{ll}\text { Payments } & \text { for } \\
\text { specific } & \text { use } \\
\text { services } & \end{array}$ & $\begin{array}{l}\text { M-Kopa* (energy) } \\
\text { Grundfos* (water kiosks) } \\
\text { Shupavu } 291 \text { (education) }\end{array}$ \\
\hline $\begin{array}{l}\text { Social support } \\
\text { ventures }\end{array}$ & $\begin{array}{l}\text { Kenyans for Kenya fundraising platform to avert starvation (Safaricom Foundation and KCB } \\
\text { Foundation partnership launched in July 2011). } \\
\text { Short Term M-Pesa Pay Bill for short term fundraising (used for education, weddings, medical or } \\
\text { funerals). Initiated between } 2012 \& 2013 \text {. } \\
\text { M-Tiba (blocked mobile wallet for health expenses since } 12 / 2015 \\
\text { Linda Jamii health insurance wallet targeting the uninsured Kenyans - since Jan } 2014 \\
\text { Sema Doc (health) } \\
\text { iCow (agriculture) } \\
\text { Shupavu (education) } \\
\text { Kilimo Salama' agricultural insurance product (Since 2009) } \\
\text { Tibu - platform to monitor, evaluate and manage TB \& other Infectious diseases. } \\
\text { Daktari-1525 (medical tele-triage service) }\end{array}$ \\
\hline $\begin{array}{l}\text { Diversified } \\
\text { ventures }\end{array}$ & $\begin{array}{l}\text {-Little cab (ride-hailing services integrated with M-Pesa) } \\
\text {-Sendy (last-mile package delivery and logistics services) } \\
\text {-FarmDrive (Farmer information for credit rating) } \\
\text {-mSurvey (a mobile research platform leveraging SMS technology) } \\
\text {-Lynk (connects informal market artisans with employers) } \\
\text {-Eneza (provides education support to primary school pupils through mobile phones) } \\
\text {-iProcure (Provides farmers with quality farm inputs at affordable prices) } \\
\text {-NEW Kenya Co-operative Creameries (KCC) cashless solution. Service targeting over } 200 \text { KCC sales } \\
\text { and milk distribution agents (since 11/2015). }\end{array}$ \\
\hline $\begin{array}{l}\text { Enhanced } \\
\text { functionality of } \\
\text { the platform }\end{array}$ & $\begin{array}{l}\text {-M-Shwari Application Programming Interface (API) upgrade in Nov } 2012 \text { for efficient money } \\
\text { transfer e.g. M-Shwari lock savings. } \\
\text {-Lipa na M-Pesa service functionality (from June } 2013 \text { ) becomes available on M-Pesa Menu under } \\
\text { "Lipa na M-Pesa". Merchants acquire a } 6 \text { digit number where customers make payments to at no extra } \\
\text { cost. } \\
\text {-M-Pesa sure pay - Service allows organizations like World Food Programme (WFP) to track funds } \\
\text { sent to beneficiaries via M-Pesa (from 03/2015). } \\
\text { - M-Pesa G2 Platform - allows secure Application Programming Interfaces (APIs) integrating third } \\
\text { party applications including Business to Customers - B2C,, Customer to Business - C2B and Business } \\
\text { to Business - B2B) (since 04/2015) } \\
\text { - Hakikisha Service allows customers to confirm the name of the recipient before any transaction (since } \\
\text { 10/2015) } \\
\text { - M-Pesa statements - Customer access M-Pesa statements by dialing } * 234 \# \text { from their handsets or via } \\
\text { email (since } 01 / 2016 \text { ) } \\
\text {-Bill manager. A new service enabling customers to manage and pay bills all in a single transaction, } \\
\text { by dialing *234* } 13 \# \text { (since } 06 / 2016 \text { ) } \\
\text {-Information of each transaction received sent to M-Pesa Customers (since } 02 / 2017 \\
\text {-Reverse transaction - M-Pesa users to reverse wrong transactions by sending the transaction code, via } \\
\text { text message, to the number } 456 \text { (since } 10 / 2017 \text { ) } \\
\text { - Safaricom, Airtel and Telecom interoperability - interoperable mobile money wallet that allows } \\
\text { transactions across Safaricom, Airtel and Telecom networks at no extra cost (since } 04 / 2018 \text { ) }\end{array}$ \\
\hline
\end{tabular}

Source: Safaricom website, 2018; media resources and insights from Lashitew, Bals, and van Tulder (2018) 